\title{
DESCRIPTIONS OF EIGHTEEN NEW SPECIES AND TWO NEW GENERA OF FISHES FROM JAPAN AND THE RIU KIU ISLANDS.
}

\author{
By John Otterbein SNyder, \\ Of Stanford University.
}

A study of the shore fishes of Japan, collected during the recent explorations of the U. S. Bureau of Fisheries steamer Albatross in the north Pacific Ocean and along the shores of Japan, was assigned to the writer by Dr. Charles H. Gilbert, naturalist in charge. Pending the preparation of a complete report, it is thought best to publish the following preliminary descriptions of new species and genera.

\section{Family LEPTOCEPHALID A.}

\section{LEPTOCEPHALUS FLAVIROSTRIS, new species.}

Head 1.7 in trunk; 3.2 in tail; 5.9 in length; head and trunk 1.2 in tail; eye 4.7 in head; snout 4.7 ; depth of body 2.3 .

Snout rather pointed, the upper jaw projecting somewhat beyond the lower; nostril tube very short; posterior nostril farther from angle of mouth than tip of snout. Branchial cleft wide, 5.7 in head, its upper edge at base of third ray of pectoral, counting from above. Mouth small, the cleft extending to a point below middle of pupil; upper lips thin, the lower somewhat thicker and pendent; tongue acutely pointed, the tip and edges free. Teeth of jaws small, slender, in bands; the bands broad anteriorly, growing narrow posteriorly where they lie in a single row; median teeth of upper jaw in a band of 4 or 5 rows, short and rather blunt.

Lateral line pores distinct, without color, 43 anterior to a point above anal opening. Dorsal inserted anterior to base of pectoral a distance equal to width of branchial cleft; membranes of dorsal and anal thin, the rays plainly showing; height of dorsal equal to length of snout, anal about equal to width of branchial cleft; caudal very short; pectorals obtuse, the upper rays longest, 3.2 in head. 
Color in spirits dark brown or blackish brown; tip of snout light; posterior half of lips light; an indefinite light area midway between eye and branchial cleft; anterior edge of branchial cleft light; pectoral dusky at base, light elsewhere; dorsal and anal broadly edged with blackish, the dorsal with oblique, very indistinct dark stripes.

The type, Cat. No. 62230, U.S.N.M., is a specimen $370 \mathrm{~mm}$. long from Misaki. Another example, slightly longer, does not differ from the above. Both were said to have come from near shore. Cotype, Cat. No. 21100; Stanford University collection.

\section{Family MURANIDA.}

\section{GYMNOTHORAX ODIOSUS, new species.}

Head 6.5 in length, 2.3 in trunk, 3.2 in tail; head and trunk equal in length to tail; depth 1.6 in head; snout 5.5 ; eye 10.5 .

Body rather short and heavy, the tail pointed. Mouth large, the eye located midway between tip of snout and angle of mouth. Teeth in a single series, rather short; 2 depressible canines in median series of upper jaw. Gill opening about equal in diameter to eye. Dorsal inserted midway between gill opening and eye, its height contained 3.6 in head. Height of anal 1.5 in snout.

Color in spirits, brown with very indistinct, dark spots which are most evident on the tail; the ground color broken up by a fine, indistinct reticulation of dull gray; snout, lips, and lower jaw lighter; fins colored like the body, the borders somewhat darker posteriorly, where they are narrowly edged with white.

Type.-Cat. No. 62231, U.S.N.M., a specimen $600 \mathrm{~mm}$. long, from Kagoshima. A rather characterless species, with a heavy body, a short tail and high dorsal.

\section{GYMNOTHORAX CHLAMYDATUS, new species.}

Head 10.1 in length; 3.5 in trunk; 5.6 in tail; depth 2.6 in head; snout 6 ; cleft of mouth 2.8 ; eye 2 in snout.

Body very long and slender, the tail pointed; jaws equal; eye about midway between tip of snout and angle of mouth. Teeth, canines of moderate size, in a single series and rather widely spaced, 8 or 9 in each side of upper jaw; 11 or 12 in the lower; 2 or 3 short, median teeth far back in upper jaw, partly concealed by the huge lateral folds of muscle in the roof of mouth; branchial cleft slightly wider than diameter of eye. Dorsal inserted midway between branchial cleft and anterior border of eye; its height on anterior portion equal to length of snout, growing gradually lower posteriorly, its height near end of tail about equal to diameter of orbit. Anal very low, about equal in height to diameter of orbit.

Color in life: Body with 13 complete light brown rings, darker on the dorsal fin and on the tail, where the last one is almost black; 
rings somewhat over half as wide as interspaces; head and interspaces spotted with same color as the rings; throat with a large, brown blotch; rings narrowly bordered with dead white, the borders gradually growing broader and becoming pearly toward the tail; areas between white borders with a pink ground color, which has an indistinct, light orange border, the latter growing deeper in tint and spreading inward on the posterior parts; under surface white, tinged with orange on the throat, bluish on the belly; tip of snout bright pink; dorsal finely spotted between the bands; anal immacrlate, except posteriorly where the body rings encroach on the fin. In spirits the body is gray, the spots and rings brown.

A remarkably beautiful eel from the market at Naha. The type, Cat. No. 62232, U.S.N.M., is a specimen $630 \mathrm{~mm}$. long. Another, slightly smaller though otherwise similar, was obtained at the same time. It is in the Stanford University collection. Cotype, Cat. No. 21101.

\section{Family LABRIDÆ.}

LEPIDAPLOIS LOXOZONUS, new species.

Three specimens of a Lepidaplois obtained in the Naha market are like that figured by Günther as L. macrumus. ${ }^{a}$ They differ markedly from the $L$. macrurus of Lacépède, ${ }^{b}$ and likewise from Crenilabrus chabrotii of Lesson, ${ }^{c}$ which no doubt is synonymous with the species of Lacépède. They have the ventrals black, and instead of a broad black band extending across the body from near the middle of the soft dorsal to the posterior third of the anal and covering half the caudal peduncle, as in $C$. macrurus, they have a conspicuous mark like a reversed comma, the large basal part of which covers the proximal half of the soft dorsal and reaches downward to the lateral line, while the tail extends downward and backward across the caudal peduncle to base of caudal fin and then outward along the edge of the inferior lobe to its tip, passing entirely free of the anal fin. A specimen similar in all points to the Naha examples is recorded from Manila by Jordan and Seale. ${ }^{d}$

The form represented by the Naha specimens and figured by Günther is here described as a new species, Lepidaplois loxozonus.

Head 3 in length to base of caudal; depth 2.8; depth eaudal peduncle 6.6 ; snout 2.7 in head; eye 5 ; interorbital width 3.8 ; D. XII, 10 ; A. III, 12 ; scales in lateral line 33 ; between lateral line and origin of dorsal 5 ; between lateral line and origin of anal 11 .

\footnotetext{
${ }^{a}$ Sudsee, pl. cxxixa.

${ }^{b}$ Hist. des Poiss., III, p. 438, pl. Ix, fig. 3.

$c$ Voy. Coq. Zool., Poiss., p. 133, pl. xxxvir.

${ }^{d}$ Bull. U, S. Bur. Fish., XXVI, p. 29.
} 
The head is pointed, the dorsal and ventral contours curved equally and evenly between dorsal, ventral and snout. The maxillary, entirely concealed beneath the suborbital, extends to a vertical through anterior edge of orbit; interorbital space convex; lips very thin, the lower with a pendent flap; upper lip with a series of very thin parallel longitudinal ridges which are broken up anteriorly, forming bunches of minute papillæ. Gillrakers short and flat, 8 on lower arch. Base of dorsal with two to three rows of scales; fin low, the rays longer than the spines; longest (posterior) spine twice the length of the first, $2 \frac{1}{2}$ in head; longest ray 2 in head. Base of anal with scales; spines graduated in length from first to third, the latter contained 3.2 in head; both dorsal and caudal reaching a vertical through end of last vertebra when depressed. Caudal truncate except for the tips of the upper and lower rays, which project about an eye's diameter beyond the posterior edge of fin; middle rays 1.6 in head. Upper rays of pectoral longest, 1.6 in head. Ventrals rather falcate, 1.3 in head, almost reaching origin of anal.

Color in spirits, 7 or 8 dusky lines extending along upper half of body from snout to a dark posterior band, the lines more or less broken up into spots on the scales; posterior part of body with a large band shaped like a reversed comma, the basal part of which covers the lower half of soft dorsal and extends to the lateral line, the tail continuing downward and backward across caudal peduncle and along lower edge of caudal fin to the tip of the inferior lobe; dorsal with a round black spot somewhat smaller than eye between second and third spines; tips of spines and rays narrowly edged with dusky; anterior half of anal black, the dark color extending along edge of posterior half of fin; ventrals jet black throughout.

Type.-Cat. No. 62233 , U.S.N.M., a specimen $205 \mathrm{~mm}$. long, from the market at Naha, Okinawa. Cotype, Cat. No. 21102, Stanford University Museum.

A dissection of the specimens in hand seems to show the presence of both sexes, though not without doubt, as the viscera are poorly preserved.

LEPIDAPLOIS MIRABILIS, new species.

Head 3.2 in length; depth 2.4 ; depth caudal peduncle 6.2 ; snout 2.5 in head; eye 4.5 ; interorbital space 3.6 ; D. XII-8; A. III-10; scales in lateral line 28 ; between origin of dorsal and lateral line 3 ; between origin of anal and lateral line 9 .

Anterior profile rather steep, curving evenly from the blunt snout to origin of dorsal; interorbital space slightly convex. Maxillary extending to a vertical through anterior edge of orbit; upper lip with longitudinal frills within, the frills replaced anteriorly by bunches of papillæ which hang down between the teeth; lower lip very thin, with pendent flaps on the sides. Gillrakers very short, 6 or 7 on lower 
arch. Teeth united into a single cutting edge which is broadened and flattened anteriorly ; a posterior canine on each side of upper jaw ; anterior part of upper jaw with 6 canines, the innermost pair minute, the outer ones considerably larger, the others equal in length to diameter of pupil; lower jaw with 4 canines, the outer ones equal in size to the largest upper ones, curving outward and backward; the inner pair somewhat smaller. Lateral line continuous, its curve following the dorsal contour of body. Snout, interorbital space and lower jaw naked; preopercle with about 5 rows of small scales, its posterior and lower borders naked, the edge smooth; opercle and the bases of dorsal and anal with scales.

Spines of dorsal low, the longest 2.7 in head, each with a thickened membrane projecting beyond its tip; membrane deeply serrated in the spinous portion, with an even edge in the rayed part. Anal with 3 strong spines, the longest (third) 2.4 in head; membrane notched between the spines, and with a thickened projection attached to each; caudal slightly concave, the length 1.3 in head. Pectoral 1.2 in head; ventrals 1.6 , rather pointed.

Color in spirits pale greenish yellow, the head and body with 7 conspicuous dark bands; the first extending over interorbital space and downward across the chin, and sending 2 transverse branches across the snout; the second passing over occiput and down across preopercle; the third crossing posterior edge of opercle; the fourth, fifth, and sixth encircling the body behind the pectoral; the seventh, equal in width to 2 of the others, crossing the posterior region between the rayed portions of the dorsal and anal and also covering the greater portion of the caudal peduncle; the first spine of the dorsal and its membrane jet black, the other spines tipped with black; the soft dorsal with a narrow black edge, the basal part dusky; caudal narrowly edged and tipped with black; anal blackish, bordered by a stripe of jet black; ventrals with an anterior black border; pectorals immaculate, teeth and the spines of fin green.

In life the anterior of the vertical bands are yellowish olive, the posterior ones becoming darker, the last purplish black; interspaces bright orange red, each bordered by a narrow band of pearly blue which fades out ventrally; posterior part of caudal peduncle greenish white; the bright colors of the body fade out ventrally, the under surface being mostly white with a bluish tinge; dorsal orange red, the spines and rays tipped with pearly blue, a stripe of the same color extending along fin just above the basal scales; anal deep red, the central portion darker, the edge pearly blue, a short, curved stripe of same color near middle of fin, below which is a faint yellow cloud; caudal tinged with yellow beyond the basal scales, then red; pectoral reddish orange at base, fading to bright yellow distally; ventral spine deep blue, the larger part of the fin dark red, bordered by pearly

Proc. N. M. vol. $\mathrm{xxxy}-08-7$ 
white; teeth vitriol green. In life this species is more brilliantly colored than any other known to the writer.

Two specimens, the type, Cat. No. 62234, U.S.N.M., measuring $190 \mathrm{~mm}$. in length, and the cotype No. 20957, Stanford University collection.

CHOEROPS JORDANI, new species.

Head 3 in length to base of caudal; depth 3.5 ; depth caudal peduncle 8.6 ; lenth snout 2.8 in head; diameter eye 4.5 ; width interorbital space 3.2 ; D. XIII, 7 ; A. III, 10 ; scales in lateral line 27 ; between lateral line and base of dorsal 2 ; between lateral line and origin of anal, counting upward and forward 9.

Anterior contour strongly arched; lower jaw projecting slightly beyond the upper; interorbital region convex, a little less so than the occiput; mouth rather large, the concealed maxillary extending to a vertical through anterior edge of pupil. Inner teeth coalesced, the cutting edge rather narrow laterally but becoming broadened anteriorly, the plates of upper jaw having a pair of small teeth at the symphysis; 4 widely spaced canine teeth in each jaw, the outer, lower ones largest, curved backward; each of the median upper pair with a small canine at its base; posterior canines large. Gillrakers very short, slender, and pointed; 7 or 8 on lower limb of first arch. Preopercle very finely serrated. Scales of cheek in 5 rows, small and nonimbricate; occiput and border of preopercle naked; 6 scales in a line between first dorsal spine and the occiput. Lateral line following contour of body to a point below beginning of soft dorsal, where it bends downward and then passes along middle of caudal peduncle. Dorsal spines highest posteriorly, the longest contained 3.2 in head; longest ray 2.8; dorsal and anal projecting an equal distance posteriorly, not reaching base of caudal. Caudal truncate, the tips of upper rays projecting; length 1.5 in head. Ventrals 1.5 in head, their tips just reaching anal opening. Pectoral 1.3 in head.

Color in alcohol pale brownish above, lighter below; a dark stripe originating just above axil of pectoral and extending to base of caudal, the lower edge coinciding with the median line of body, the stripe broadening gradually posteriorly, the dorsal edge passing upward to base of last dorsal spine and intruding somewhat on base of soft dorsal; broad posterior part of stripe including an oblong yellowish spot which passes saddle-like over the caudal peduncle; upper edge of caudal dusky.

Four specimens from the market at Naha.

Type-Cat. No. 62235, U.S.N.M., 135 mm. long. Cotype, Cat. No. 21103, Stanford University collection.

Named for President David Starr Jordan of Stanford University. 
Family SCARIDA.

CALLYODON LUNULA, new species.

This species closely resembles Callyodon bataviensis Bleeker ${ }^{a}$ and also $C$. elere Jordan and Seale. ${ }^{b}$ It differs from the former in the absence of lateral canines, in not having a median dark stripe on the dorsal, and in having 2 green bands across the interorbital area and a row of scales on the lower edge of the preopercle. From $C$. elere it may be known by the white teeth without lateral canines, the long lips which cover the teeth, the very small scales on the lower limb of preopercle, and the more arched interorbital space with its 2 green bands, $C$. elere having the largely exposed teeth deep green in color, with prominent white lateral canines, 4 large scales on lower edge of preopercle, the interorbital space lower and of one color.

Head 3 in length; depth 2.7; depth caudal peduncle 6.2 ; eye 6.5 in head; snout 2.7; interorbital space 2.7; scales in lateral series 21; between origin of anal and base of dorsal, counting upward and forward $9 ;$ D. IX, $10 ;$ A. II, 9.

Anterior profile rather abrupt, the interorbital area with an evident hump, making the position of the eye appear somewhat low. Lips full, almost covering the teeth. Teeth white; no lateral canines present; 3 rows of scales below eye, a row of 2 or 3 small scales on lower limb of preopercle, 4 scales anterior to origin of dorsal, 5 rows on caudal peduncle. Posterior dorsal spines slightly longer than anterior ones, height 3 in head; rays somewhat higher than spines. Anal equal in height to spinous dorsal. Lobes of caudal projecting beyond the otherwise truncate edge. Pectoral 1.5 in head; ventral 1.5.

Color in spirits brownish tinged with green, each scale with a lighter edge; middle of chin and throat deep green; a green stripe passing from chin to lower edge of orbit; a similar stripe passing obliquely downward and backward across upper lip and uniting with another which fringes the lower lip, extends upward and backward through lower half of eye; upper lip edged entirely with green; 2 green bands passing over the interorbital area; dorsals and anal with a broad basal stripe of green and a narrow edging of the same color; caudal bordered with green above and below ; a green crescent on posterior part of fin, the cornua of which reach the tips of the lobes; upper edge of pectoral green, the basal portion suffused with same color.

Type-Cat. No. 62236, U.S.N.M., measuring $403 \mathrm{~mm}$. in length, from the market at Naha, Okinawa. But 1 specimen obtained.

${ }^{a}$ Java, IV, p. 342.

${ }^{b}$ Bull. U. S. Bur. Fish., XXVI, p. 31, fig. 11. 


\section{Family GOBIID Æ.}

HETERELEOTRIS ARENARIUS, new species.

Head 3.5 in the length; depth 6.5 ; depth caudal peduncle 9.2 ; snout 4 in head; eye 7.2 ; interorbital space 4 ; D. VI, 12 ; A. 10 ; scales in lateral series 35 ; transverse 12 .

Head rather long, broad and flat; eyes located high up, their rims projecting above contour of head, directed upward more than sidewise; interorbital space flat; cleft of mouth broad, oblique, falling far short of a vertical through anterior edge of orbit; lower jaw slightly projecting. Jaws with simple teeth in bands; no canines; no teeth on vomer and palatines; tongue truncate. Gill opening restricted to the sides, extending downward somewhat below base of pectoral. Nostrils tubular, the anterior one near tip of snout. Head and nape naked; 5 large mucous pores behind eyes; snout with several fringed dermal flaps; side of head with 4 beaded dermal ridges, the lowermost of which bears a few elongate barbels and extends from chin backward, curving upward in region of edge of opercle; throat with barbels. Body with large cycloid scales, somewhat ctenoid posteriorly; about 35 in a lateral series, 12 or 13 in a transverse series; abdomen with scales; scales of sides and ventral-surface partly or entirely concealed in fresh specimens; no lateral line.

Dorsals separate, the anterior with 6 slender spines, the posterior with 12 rays; anal of 12 rays inserted below base of third dorsal ray; no membranes connecting posterior rays of dorsal or anal with body; both fins extending an equal distance posteriorly when depressed. Caudal obtusely pointed, 4.5 in the length. Pectoral similar in shape, 4.8 in the length. Ventrals united, free from the abdomen, the rays slender, the longest contained about 5.5 times in the length; membranes of fin thin and frail.

Color in spirits pale yellowish; dorsal region of head brown; back crossed by 4 brown bands, the first above bases of pectorals, the second through base of spinous dorsal, the third and fourth through base of soft dorsal; side of body with a broad brown stripe which unites with the dorsal crossbands and sends 4 or 5 projections downward on the sides, and extending on base of caudal fin abruptly widens to form a narrow vertical band.

Type.-Cat. No. 62237, U.S.N.M., an example $270 \mathrm{~mm}$. long, from Naha, Okinawa. Cotype, Cat. No. 21104, Stanford University collection, from Tanegashima.

The species, represented by 2 specimens from Okinawa and 3 from Tanegashima, was found in sandy pools, and appears to be rare. It is referred with some doubt to the genus Hetereleotris, ${ }^{a}$ and is 
apparently related to $H$. $\operatorname{clar} a$ Jordan and Seale. ${ }^{a}$ That species, however, is not naked, but has the body covered with scales, according to Mr. B. A. Bean, who has kindly reexamined the type.

GNATHOLEPIS SINDONIS, new species.

Head 3.4 in length to base of caudal; depth 3.5 ; depth caudal peduncle 6.2 ; eye 4 in head; snout 2.8 ; width interorbital space 2 in eye; D. VI-12; A. 10 ; scales in lateral series 24 ; in series between insertion of anal and dorsal, counting upward and forward, 10.

Body rather deep and short, the head large; jaws equal; eye nearer tip of snout than origin of dorsal by a distance about equal to its diameter. Mouth oblique, the maxillary extending to a vertical through anterior edge of orbit. Teeth simple, in narrow bands on the jaws; none on palatines and vomer; tongue truncate; gillrakers short, rather slender and pointed.

No barbels or conspicuous mucous pores. Body with large, ctenoid scales; those on occiput, nape, and throat cycloid and not greatly reduced in size; scales on base of pectoral small; snout naked; cheeks with large, cycloid scales which are divided into three distinct patches by lines of minute pores; opercles with large, ctenoid scales. Dorsal fins separate, the spines very high and slender, the longest (second) contained 3 times in the length; membrane scalloped between the spines; soft dorsal high, the longest rays $4 \frac{1}{2}$ in the length, the depressed fin just reaching base of caudal; anal when depressed not reaching base of caudal; neither dorsal nor anal connected with caudal peduncle by membrane; pectoral obtusely pointed, 3.3 in the length; ventrals completely united, 4.5 in the length.

Color in spirits very pale brownish, the posterior scales with scarcely perceptible light centers; anterior part of body with an indefinite dusky mantle which extends backwards about to tip of pectoral, the included scales having dark spots; spinous dorsal with elongate dusky spots arranged in about 6 oblique rows; soft dorsal and upper two-thirds of caudal with small dusky spots; ventrals with inner parts dusky.

One specimen, the type, Cat. No. 62238, U.S.N.M., from the Naha market, Okinawa, measures $110 \mathrm{~mm}$. in length.

Named for Mr. Michitaro Sindo.

AMBLYGOBIUS NARAHARAE, new species.

Head 3.5 in length to base of caudal; depth 3.7 ; depth of caudal peduncle 2.1 in head; eye 3.2 ; snout 4.7 ; D. VI-12; A. 10 ; P. 18 ; scales in lateral series 30 ; in transvere series above anal 11. 
Body notably thick-set, deep, and compressed; head wide, snout blunt; eyes high in head, the dorsal rims projecting high above contour of head; interorbital space very narrow, its width equal to about one-half the diameter of pupil. Mouth oblique, the lowe: jaw projecting slightly beyond the upper; jaws with narrow bands of minute teeth bordered on the outer and inner edges by a row of larger teeth, one of which is developed as a canine on each side of lower jaw; tongue large, truncate anteriorly; gillrakers slender and pointed. Both nostrils tubular. Mucous pores of head papillose, arranged in rows.

Body, including nape, throat, abdomen, and bases of pectorals, covered with weakly ctenoid scales; cheeks naked; upper edge cf opercles with a few large scales.

Dorsal fins separate, the spines slender, about equal in height to rays, 1.7 in head; posterior rays when depressed just reaching base of caudal. Anal equal in height to soft dorsal, the rays when depressed not reaching caudal. Pectoral large, obtusely pointed; the length of longest rays equal in length to head. Ventrals pointed, the membranes delicate and easily parted; length, 1.4 in head.

Color in spirits dusky, each scale with a dark edge; head and body with 12 light, vertical bands, the anterior two passing through eye, the third touching posterior edge of orbit, fourth crossing opercle, fifth on base of pectoral, seventh passing between dorsals, sixth, eighth, and ninth extending upward on dorsals, tenth, eleventh, and twelfth on caudal peduncle; dorsals and caudal with minute dark spots; other fins immaculate.

Type.-Cat. No. 62239, U.S.N.M., a specimen $50 \mathrm{~mm}$. long, from a tide pool at Naha, Okinawa.

Three smaller examples are somewhat brighter in color than the type, but appear to differ in no other particular.

One example was taken at Tanegashima.

Cotype, Cat. No. 2110็, Stanford University collection.

Named for Baron Shigeru Narahara, governor of Okinawa.

\section{Genus DORYPTENA, new.}

Body elongate, nearly cylindrical, the head broad and rather flat, cheeks bulging; head with beaded dermal flaps and ridges; tongue small and truncate; teeth simple, in narrow bands on both jaws, those of outer row slightly enlarged; vomer and palatines without teeth; isthmus broad; gillrakers long and pointed; head and breast naked, body with small cycloid scales; dorsals separate, spines 6 , rays 12 to 15 ; caudal and pectorals long and pointed, the latter without detached rays; ventrals completely united.

Two known species living along the shores of southern Japan and the Riu Kiu Islands.

Type of the genus.-Doryptena okinawae, new species. 
DORYPTENA OKINAWAE, new species.

Head 4.2 in length to base of caudal fin; depth 6.2 ; depth of caudal peduncle 2.3 in head; eye 4.5 ; snout 4 ; D. VI-12; A. 9 ; P. 15 ; scales in lateral series about 50 ; in transverse series above origin of anal 16 .

Body elongate, subcylindrical, the caudal peduncle compressed. Head broad, depressed, the cheeks bulging out beyond eyes which are directed obliquely upward, their rims extending somewhat above dorsal contour of head. Mouth terminal, broad, the maxillary not extending posteriorly halfway from snout to eye. Head with many conspicuous beaded dermal flaps and ridges; mucous pores of head with pronounced rims or tubes; nostrils with large tubes. Tongue small, narrow, truncate anteriorly. Teeth on both jaws simple, in narrow bands, those of the outer row slightly enlarged; vomer and palatines without teeth. Isthmus broad, the gill clefts extending downward to a level with lower edge of base of pectoral. Gillrakers long and pointed, 8 on lower side of arch.

Head and breast naked; body except base of pectoral and breast anterior to ventrals with imbricate, cycloid scales, a little larger posteriorly where there are several greatly enlarged ones near middle and posterior part of caudal peduncle; smaller anteriorly, minute and crowded above base of pectoral.

Dorsals separated by a distinct space; spines slender, the third or fourth longest, 1.6 in head; tip of soft dorsal overlapping base of caudal, the next to last ray longest, 1.2 in head; tip of depressed anal not reaching base of caudal, the rays about equal in length to those of dorsal. Caudal pointed, 2.7 in the length; 3 rays near middle of fin conspicuously beaded by small tubercles. Pectorals pointed, none of their rays detached, 3.5 in the length. Ventrals united, the tips of rays free, giving edge of fin a frayed appearance; 4.7 in length.

Color in spirits brownish, with a faintly outlined dark saddle over back near middle of spinous dorsal; a similar though scarcely noticeable mark below base of soft dorsal; a faint, narrow, dark band extending backward from snout through eye to upper edge of gill opening. Spinous dorsal clouded with dusky; other fins lightly spotted on the rays; spots of dorsal and anal arranged in oblique lines; those af caudal in somewhat broken vertical rows.

Described from type Cat. No. 62240, U.S.N.M.; length, $64 \mathrm{~mm}$. Locality, Naha, Okinawa, where the species is rather common in the tide pools. Cotype, Cat. No. 21106, Stanford University collection.

Small examples are more brightly colored than the larger ones. The background is lighter and the dark parts are more prominent and well defined. A distinct dark band extends downward from eye, and another appears on base of caudal. 
Color in life, body dark brown, each scale with a lighter area; stripes of head brownish gray, the cheeks with vertical, whitish lines; throat tinged with orange; spinous dorsal, pectorals, and ventrals suffused with yellow; soft dorsal and anal dark brown, the rays of the former tipped with yellow.

DORYPTENA TANEGASIM在, new species.

Head 5 in length to base of caudal fin; depth 7 ; depth of caudal peduncle 2.5 in head; eye 4 ; snout 3.8 ; D. VI-15; A. 13 ; P. 15 ; scales in lateral series about 57 ; in transverse series above anal about 18 .

Body markedly elongate, subcylindrical, the caudal peduncle compressed; head broad, depressed; cheeks bulging far out beyond eyes, which are directed obliquely upward. Head with conspicuous beaded dermal flaps and ridges which are definite and intricate in their arrangement; mucous pores of head with pronounced rims or tubes, prominent among which are 2 minute black tubes on occiput; nostrils with large tubes. Mouth terminal, broad, but with a very narrow cleft, the maxillary not reaching over halfway to eye; tongue small, narrow, truncate anteriorly; teeth simple, in narrow bands on both jaws, those of outer row slightly enlarged, vomer and palatines without teeth. Isthmus broad, the gill clefts extending downward to a level with lower edge of base of pectoral. Gillrakers long and pointed, 8 on lower side of arch.

Sides of body with a series of 18 or 20 small, vertical, beaded ridges, the longest about equal in length to cleft of mouth. Head entirely naked; breast, base of pectoral and axil naked; scales of body very thin, minute, cycloid, far apart, and deeply embedded in the epidermis.

Dorsal fins barely separate, their bases nearly connected by membrane; spines slender and very flexible, the longest (third) contained 1.8 in head; rays higher than spines, the next to last longest, about equal in length to head. Anal lower than dorsal, not extending so far posteriorly, although the tips of both overlap bases of upper and lower caudal rays. Caudal sharply pointed and extremely long, 2.2 in the length. Pectorals with a strong muscular base somewhat like that of Periophthalmus, the upper rays not separate, the middle ones much the longest, about 4 in the length, the fin pointed like the caudal. Ventrals completely united, the length about equal to that of head.

Color in spirits light brown, a minute white spot on each scale; a conspicuous narrow dark brown saddle over back at middle of spinous dorsal, posterior to which are 3 others, the third being the most prominent, the fourth narrow, on end of caudal peduncle; head with a faint dark bar extending from tip of snout through eye to occiput, narrow anteriorly, broader posteriorly where it almost meets 
bar on opposite side; sides of head with round light spots; fins checkered with brown spots. In young examples the general color is brownish gray, the bars standing out boldly, except the second on body, which is often indistinct or even absent.

The species is here described from the type Cat. No. 62241, U.S.N.M., a specimen $96 \mathrm{~mm}$. long from Tanegashima, where it is rather common in the tide pools. Examples were also taken at Akune in Satsuma. Cotype is Cat. No. 21107, Stanford University collection.

Genus XENISTHMUS, new.

Body elongate, head pointed, lower jaw projecting. Tongue free, rounded. Teeth simple, in a single row on jaws. Gill-membranes extending forward below and uniting, their edges free from the isthmus. Edge of shoulder girdle with a tooth. Head naked, body with small cycloid scales. Dorsals separate; soft dorsal and anal free from the caudal; ventrals separate, divided at the base.

One species known, from Naha, Okinawa.

Type of the genus.-Xenisthmus proriger, new species.

XENISTHMUS PRORIGER, new species.

Head, measured from tip of upper jaw, 4.3 in length to base of caudal; depth 6.5 ; depth of caudal peduncle 2.1 in head; eye 5 ; snout 5; D. VI-14; A. 13 ; P. 15 ; scales in lateral series about 56 ; in transverse series above anal 20 .

Body deeper than wide; head long and pointed; lower jaw projecting considerably beyond upper; maxillary extending to posterior part of pupil. Tongue large, free, rounded at tip. Teeth simple, in a single row on jaws, none on vomer and palatines. Gill-membranes extending forward below and uniting, their edges free from the isthmus. Inner edge of shoulder girdle with a tooth covered by a small dermal protuberance. Gill-rakers on first arch 3-9, long, slender, and pointed. Anterior nostrils tubular; the posterior ones with a large dermal flap.

Head entirely naked; a row of minute dermal tubercles extending backward from tip of maxillary along lower edge of cheek; a conspicuous mucous pore behind eye; 5 similar ones on top of head arranged thus (: : :). Body, including throat, breast, nape, and bases of pectoral fins, with slightly ctenoid scales of medium size, which are largest on caudal peduncle.

Dorsals separate, the first with slender spines about equal in length to the rays, the longest (third and fourth) contained 2.5 in head. Anal slightly higher than first dorsal, the longest (middle) rays 2.1 in head; first ray inserted below base of second dorsal ray; base of fin not extending quite so far posteriorly as that of dorsal, the tips of neither anal nor dorsal touching base of caudal when depressed. 
Caudal evenly rounded, slightly shorter than head. Pectorals rounded, 1.3 in head. Ventrals separate, divided at base, 1.5 in head. Anal papilla about equal in length to diameter of eye.

Color in spirits; dorsal part of head and body, chin, throat, and abdomen creamy white; sides covered with minute dots, closely grouped so as to form a tolerably definite brown stripe extending from point of lower jaw and snout through eye, across cheek, base of pectoral, and along lower part of body to near end of caudal; the color stripe more intense on the head and caudal fin, where it is more or less broken up into spots; dorsals with a few minute, indistinct spots extending in a line along middle of fins; anal, pectorals, and ventrals immaculate.

Described from the type Cat. No. 62242, U.S.N.M., a specimen $33 \mathrm{~mm}$. long, from a tide pool at Naha, Okinawa. Cotype, Cat. No. 21108, Stanford University collection.

Two smaller specimens do not appear to differ from the type.

\section{Family BLENNIIDA.}

ALTICUS MARGARITARIUS, new species.

? Salarias biseriatus Kner, Novara Reise, Fische, p. 197, pl. viII, fig. 5.Jordan and Seale, Fishes Samoa, Bull. U. S. Bur. Fish., XXV, 1905, p. 427. Not of Cuvier and Valenciennes, Hist. Nat. Poiss., XI, p. 316, nor of GÜNTHER, Fische der Südsee, p. 208.

Head 4.8 in length to base of caudal; depth 5 ; depth caudal peduncle 10.3 ; eye 4 in head; interorbital space 6 ; D. XII, 19 ; A. 22 ; P. 15 .

Anterior profile of head vertical, the outline convex; head narrowed above, broadened below, the cheeks prominent. Eyes located in anterior upper part of head, their rims projecting slightly above the dorsal contour, directed somewhat forward and upward. Mouth inferior, very broad, the lips full and pendulous at the corners; both jaws with a single row of long, slender, close-set teeth, loosely embedded, and arranged in groups of seven, the median ones of which are higher than the others, thus giving the cutting edge of the jaw a scalloped appearance; 2 large canines in lower jaw, each fitting a pit in the roof of mouth. Large pseudobranchiæ present; gillrakers very short, pointed, 11 or 12 on first arch. Head with a crest about equal in height to diameter of eye; the anterior and posterior edges vertical. Upper border of eye with a long cirrus, the edge of which is fringed; posterior nostril with a pointed cirrus.

Lateral line of widely spaced, elongate tubes, decurved above pectoral, disappearing at a point beneath tip of fin.

Dorsal fins with a dividing cleft, but connected at bases by membrane; longest spine 1.8 in head; ray, 1.2. Origin of anal below base 
of tenth dorsal spine; both dorsal and anal free from caudal, the depressed rays extending a short distance beyond base of fin; membrane of anal deeply scalloped between the rays; posterior ray not connected with caudal peduncle by membrane; longest ray 2 in head. Caudal of peculiar shape, the lower median rays somewhat longer than those above, the ventral rays growing successively shorter, giving the lower portion of the fin, when not expanded, the appearance of being clipped. Pectoral rather acutely rounded, the length being equal to that of head. Ventrals 2 in head.

Color in spirits dusky, with two rows of pearly ocelli along the side of body and numerous smaller ones along the back; the cheeks with numerous and distinct black specks; sides of body with 6 indistinct, dark bands, each being divided and more apparent on the back, and also extending upward on bases or dorsals; first dorsal with an indistinct, dark spot between first and second spines, and a brownish edging which grows broader posteriorly; second dorsal broadly edged with brownish; both fins with numerous pearly spots, those of second dorsal elongate and narrow, especially so, near base of fin. Anal and caudal with very indistinct light spots. Pectoral with minute black specks. Ventrals dusky.

The shape of the head shows some variation, the anterior outline being often straight instead of convex; usually vertical but in some cases sloping backward. The crest is occasionally very low. In some examples the dark lateral bands are each completely divided; in others the pearly spots are not distinctly ocellate, the margins being scarcely dusky. In ten examples the dorsal spines are 12 in number, the rays 18 or 19 , the anal rays 19 to 22 .

Type.-Cat. No. 62243, U.S.N.M., a specimen $72 \mathrm{~mm}$. long, from the pools at Tanegashima. Cotype, Cat. No. 21109, Stanford University collection.

This is certainly not the S. biseriatus of Cuvier and Valenciennes nor of Günther, as those authors distinctly say that there are no canines. Canines are present, however, and their great size precludes any possibility of their being overlooked. It may possibly be the species described and figured by Kner, although he is equally positive about the absence of canines.

\section{ALTICUS NOVEMMACULOSUS, new species.}

Head 5 in length to base of caudal; depth 5.4 ; depth caudal peduncle 10.3 ; eye 3.8 in head; width interorbital space 11 ; D. XII, 21 ; A. 23 ; P. 14.

Anterior contour of head concave, the line in front of eyes bulging outward; eyes very close together, their vertical diameter longest, the anterior edge of orbit almost directly above edge of upper lip. A low crest on head, the anterior edge of which slopes gradually 
backward; a simple tentacle above eye; a branched one on anterior nostril. Mouth broad, inferior, the lips pendalous at angles. Teeth slender, simple, loosely attached; in a single row, the cutting edge even; strong, curved canines on inner side of lower jaw. Pseudobranchiæ large; gillrakers on first arch 12, very short, their tips widened and digitate. Lateral line arched over pectoral, ending just above tip of depressed fin.

Dorsal inserted directly above upper edge of gill opening; connected with base of caudal by membrane; a deep notch between spinous and rayed portion; spines much lower than rays, 1.5 in head; longest (middle) rays about equal in length to head. Origin of anal below bases of eleventh or twelfth dorsal spines, not connected with caudal, the posterior ray having no membrane back of it; membrane of anal deeply scalloped between the tips of rays; longest ray 1.3 in head. Caudal rounded, the lower rays somewhat more stiff than the upper ones and close together, the fin having a worn appearance on the inferior edge; middle rays 4.5 in the length. Pectoral obtusely pointed, its length 1.2 in head, the base muscular. Ventrals 1.8 in head.

Sides with 9 conspicuous brownish spots, the anterior ones large and connected by upward extensions which intrude on bases of dorsals, the posterior 2 very small; indistinct, narrow, dark lines extending along sides; a sharply outlined, blue-black spot on upper edge of opercle; a narrow, slightly curved, vertical band behind eye, and a similar though less distinct one extending downward from eye. Spinous dorsal very dark above and with numerous narrow, elongate, black spots; soft dorsal with small, closely apposed, brownish spots on the upper portion, the lower part with oblique, sharply defined, black lines, interrupted on the rays and growing less distinct posteriorly. Anal with a broad, dark margin. Caudal with many small pearly spots; the lower border dusky, the posterior white. Pectorals with a few minute, black specks.

This description is of a brilliantly colored male specimen. Other male examples of the species are duller in appearance, the bands of the sides being indistinct and dark lines appearing on the body. In some cases the anterior spots have ventral projections.

The females are so different that they might be mistaken for another species. The occipital crest is very low, sometimes scarcely evident; the dorsals, caudal, and anal are checkered, and the lateral bands send downward projections on the ventral parts of the sides.

Reference to a number of specimens gives the following fin formula: D. XII or XIII, 20 or 21 ; A. 22 or 23 . The species appears to be abundant at Naha, fairly swarming in some of the pools.

Type.-Cat. No. 62244, U.S.N.M., a specimen $99 \mathrm{~mm}$. long from Naha, Okinawa. Cotype, Cat. No. 21110, Stanford University Museum. 
SALARIAS MUSCARUS, new species.

Head 4.5 in length to base of caudal; depth 5.2 ; depth of caudal peduncle 2.2 in head; eye 3 , interorbital space 8 ; D. XII, 20; A. 21 ; P. 14.

Eyes placed far forward and elevated, the rims projecting above dorsal contour of head. Forehead not projecting beyond mouth. Mouth inferior, the jaws each with a band of minute, bristle-like, loosely attached teeth; no canines. No crest on head; a minute cirrus en each side of occiput, a long, slender one on upper part of eye, and a branched tentacle on nostril. Lateral line curved above pectoral; not extending beyond tip of depressed fin.

Dorsals separated by a deep notch, the membrane extending over basal third of first ray; origin of spinous dorsal directly above gill opening, its height less than that of articulated portion, 2 in head; longest ray 1.5. Origin of anal below eleventh dorsal spine, the longest ray 1.6 in head; both dorsal and anal free from caudal. Caudal truncate, 1.1 in head. Pectoral acutely rounded, equal in length to head.

Color in spirits light brownish gray, the sides with 7 dark cross bands which are divided above and below, the upper branches extending on bases of dorsals, the lower tapering and disappearing on ventral region; head, bases of pectorals and region above them with minute white specks; body, posterior to pectorals, with many irregularly placed, sharply outlined, black specks; spinous dorsal with numerous small brown spots; anal with a broad dusky margin, the rays tipped with lighter; caudal with 2 dusky spots at base; pectoral immaculate.

One specimen, the type, Cat. No. 62245, U.S.N.M., from Naha, Okinawa, $50 \mathrm{~mm}$. long.

SALARIAS SINUOSUS, new species.

Head 4.4 in length to base of caudal; depth 4.2 ; depth of caudal peduncle 2 in head; eye 2.8 ; interorbital space 5 ; D. XI, 18; A. 20 ; P. 14.

Eyes large, far forward, their edges projecting beyond anterior profile. Mouth inferior; lips with deeply scalloped edges; teeth minute, loosely embedded, no canines; large pseudobranchiæ present; gillrakers short, pointed, 17 on first arch. No crest; a pair of minute tentacles on nape, a slender filament on upper part of eye, and a branched tentacle on nostril. Lateral line extending above pectoral and ending shortly beyond tip of depressed fin. Dorsal inserted directly above gill opening, the spinous and articulated parts separated by a notch, the membrane extending upward beyond middle of 
first ray; edge of membrane more deeply incised between spines than between rays; highest spine 1.6 in head; ray 1.3. Origin of anal below eleventh dorsal spine; third, fourth, and fifth rays élongate; neither anal nor dorsal attached to caudal by membrane. Caudal truncate, the length equal to that of head. Pectoral rather pointed, nearly equal in length to head.

Color in spirits pale brownish gray, the black peritoneum showing through the abdominal walls; a dark spot on upper part of opercle; edge of preopercle dusky; chin and upper lip mottled; body with an irregular series of small, round, sharply defined, black spots along upper side, below and above which are numerous dark specks, some of which are closely clustered, forming vermiculations on sides of abdomen. Dorsal dusky; a series of indistinct, elongate, narrow bars extending obliquely upward and backward from base to near middle of fin; caudal speckled on median portion; an indistinct, dusky spot cn posterior part below center of fin; anal dusky, with an indistinct, white border and a light basal area.

Described from the type, Cat. No. 62246, U.S.N.M., an example 43 mm. long, from Naha, Okinawa. Cotype, Cat. No. 21111, Stanford University collection.

The filamentous anal is a character peculiar to the male sex. The female differs from the male in this particular only, the anterior anal rays being somewhat shorter than the others. The females appear to be slightly larger than the males. In 6 specimens there are 18 to 20 anal rays.

The species resembles $S$. undecimalis ${ }^{a}$ from the Philippines. It differs from $S$. undecimalis in having a branched nostril tentacle, scalloped upper lip, a less projecting forehead, and in color.

ENCHELYURUS HEPBURNI, new species.

Head 4.5 in length to base of caudal; depth 4.4 ; depth of caudal peduncle 2.5 in head; eye 3.5 ; interorbital space $4 ; \mathrm{D}$. XII, 17 ; A. $22 ;$ P. 13.

Body deep; the head large. No crest or filaments; a small flap on nostril. Each jaw with a row of strong, flat, closely apposed teeth bordered on either side by a very strong, curved canine. No pseudobranchiæ; gillrakers very short and blunt. Gill opening restricted to a small slit somewhat less in width than diameter of eye, and entirely above the base of pectorals. Dorsals without notch, the origin directly above gill opening, the posterior part connected with caudal by membrane; articulated rays 18 , none of which are branched; longest rays near posterior part of fin, their length contained 1.5 in head. Anal originating below tenth dorsal spine, connected with base of caudal by membrane; the longest (posterior) 
rays, 1.8 in head. Caudal rounded; more than half of fin free from dorsal and anal; length 1.2 in head. Pectoral rounded, 1.3 in head. Ventrals 1.4 in head; the rays cleft almost to bases. Lateral line complete, represented by scattered pores curving above the pectoral.

Color in spirits blue black without variation of any sort, except a very narrow, white border on anal, including only the tips of the rays and the edge of the scalloped membrane, and also an indistinct light border on the caudal.

Type.-Cat. No. 62247, U.S.N.M., Naha, Okinawa, measuring 42 mm. long. Cotype, Cat. No. 21112, Stanford University collection.

Five cotypes show a variation of 29 to 30 rays in the dorsal fin.

The species is easily distinguished from $E$. ater ${ }^{a}$ in the more posterior insertion of the dorsal, the rounded caudal, which is more free from dorsal and anal, and also in having a more restricted gill opening, the latter, in examples of $E$. ater from Pago Pago, extending downward to near middle of base of pectoral. From $E$. flavipes ${ }^{b}$ this species differs in having 29 or 30 dorsal rays instead of 33 , and the plain color. The description of E. flavipes, without illustration, is entirely too brief for use in identification, and this form may possibly prove to be identical with it.

Named for Lieut. A. J. Hepburn, U. S. Navy, executive officer of the U. S. Bureau of Fisheries steamer Albatross.

${ }^{a}$ Gïnther, Fische der Südsee, p. 199, pl. cxv, fig. c.

${ }^{b}$ Peters, Monatsb. k. preuss. Akad. Wiss. Berlin, 1868, p. 268. 


\section{$2 \mathrm{BHL}$ Biodiversity Heritage Library}

Snyder, John Otterbein. 1908. "Descriptions of eighteen new species and two new genera of fishes from Japan and the Riu Kiu Islands." Proceedings of the United States National Museum 35, 93-111. https://doi.org/10.5479/si.00963801.1635.93.

View This Item Online: https://www.biodiversitylibrary.org/item/32327

DOI: https://doi.org/10.5479/si.00963801.1635.93

Permalink: https://www.biodiversitylibrary.org/partpdf/27571

\section{Holding Institution}

Smithsonian Libraries

\section{Sponsored by}

Smithsonian

\section{Copyright \& Reuse}

Copyright Status: NOT_IN_COPYRIGHT

This document was created from content at the Biodiversity Heritage Library, the world's largest open access digital library for biodiversity literature and archives. Visit BHL at https://www.biodiversitylibrary.org. 